\title{
THEORY OF CHANGE: A SUCCESS OR A FAILURE FOR SCHOOL IMPROVEMENT, A DISCUSSION BASE ON MALAYSIAN CONTEXT
}

\author{
R. Sudha Nair \\ Putra International College, Malaysia
}

\begin{abstract}
This is a review paper aim to analysis Michael Fullan's article of Theory of Change (2006). In his article, he had discussed based on three sections which are flawed change theories, theories of action with merit and what the prospects are for future of these theories of change in knowledge. In each section, topics have been broken further into smaller components and analyzed. This paper provides comparison and contrast base in the context of the researcher's own background. The Theory of Change base in Malaysian context is looked upon as a challenge and even though there are many that are agreeable to Fullan's article, there are also drawbacks. The paper is presented with ideas, theories and other research in this field, thus providing a review of relevant literature to support the researcher's arguments.
\end{abstract}

Keywords: Theory of Change, Success, Failure, School Improvement

\section{Introduction}

The Canadian grand wizard of "school change," Dr. Michael Fullan, the author of the article of Change Theory: As a Force for School Improvement is still on top and controlling the public agenda after three decades. As a "Senior Advisor" to the Ontario Premier and Minister of Education since April 2004, and a former Dean of Education at University of Toronto (1988-2003), he exerts a powerful but largely hidden influence over the school reform agenda in Ontario, Britain, and far beyond. He is noted for his knowledge on educational reform, and has consulted to school districts, teacher groups, research institutes, and governments.

Change theory as a force for school improvement by Michael Fullan (2006), discusses three main issues in his article. These include the drawbacks of change theories, the theories of action which produce results and its prospects for future use. The author has highlighted the flaws that exist in changed theories and how it is not producing the change that is required out of it.Gabriele (Susan, 2002) in her article "The "roundtable" for school learning and planning groups mentioned that different theories approach in a systemic educational change varies in philosophies, strategies, models, and methods and searching for the theory that will create conditions is necessary for systemic change.In order to achieve this Gabriele declared that conditions to include would be an "ideal-based, holistic, continuing, participatory, user-friendly, easy to adjust/improve, and emancipatory" for effective change to occur in education (Susan 2002). As such, it does not come as a surprise that the many theories of educationthat exist have weaknesses and flaws. Fullan (2006) claims that the flaws can be seen in the standard based reform initiatives, professional learning communities or framework that focus on the development and retention of quality leaders in schools.Fullan had also discussed what theories of action appear to have more merits (theories with better results) and using the changed knowledge more fully so that it can be benefited in future. These theories of actions are a set of assumptions about how one can move from its current state to its desired future (Elmore, Fiarman, and Teitel, 2009) and Fullan has identified seven core premises which are motivation, capacity building, learning in and changing context, a bias for reflective action, tri-level engagement and finally persistence and flexibility in staying the course. Fullan also discusses the negative aspects of these components.

The author has given ample of examples to prove his points (Refer Figure 1 on the topics that will be discussed). This approach has its roots in the 1960s, when Kirkpatrick used the model to examine the effects of training on students (Eseryel, 2002). It has grown in recognition in the last two decades, partially in response to the need

Corresponding Author:R. Sudha Nair/ sudha@iputra.edu.my/rsn2001my@yahoo.com

$3^{\text {rd }}$ International Conference on Education, 20-22 April 2017, Kuala Lumpur, Malaysia 
for a framework that can take into account the barrier of multi-stranded and interrelated actions to promote social change.

\section{Theory of Change}

Brest (2010) defined Theory of Change as initiative or program logic. He explains that it defines long-term goals and then maps backward to identify changes that need to happen earlier (preconditions). According to Brest, interventions, which are activities and outputs of any sort, are mapped to the outcomes pathway to show what stakeholders think it will take to effect the changes, and when.

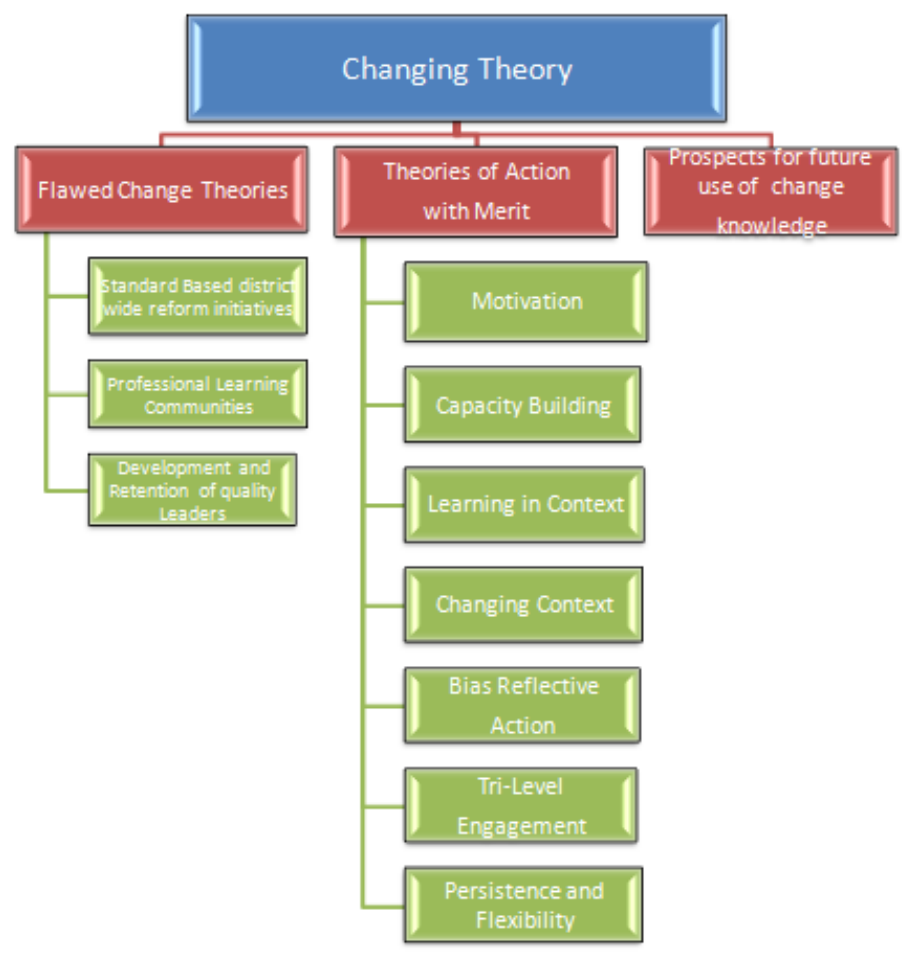

Figure 1 Changing Theory: A force for school improvement

\section{School Improvement}

Hopkins (2003) defines school improvement as a distinct approach to educational change that aims to enhance student outcomes as well as strengthening the school's capacity for managing change. Barth (1990) defines school improvement as, an effort to determine and provide, from within and without, conditions under which the adults and youngsters who inhabit schools will promote and sustain learning among them. According to these definitions, the purpose of school improvement is to impact the relationship between the teaching and learning process and the conditions that support it. Further, the change which should take place as a result of the school improvement effort should not merely reflect an implementation of policies, but rather, improvements or adaptations of practice which transform the learning process to achieve the maximum impact on students, teachers and schools (Hargreaves, 1994; Hopkins, 2003). There is a shift in school improvement paradigm over the years due to the advancement of technology in Malaysia. School improvement efforts are more focused on capacity building, improved teaching and learning processes, high level student learning outcomes, and creating a community of learning amidst a digitized learning environment (Abdullah, DeWitt, and Alias, 2013). 


\section{Discussion Base on Fullan's Framework}

\section{Flawed Change Theories}

Fullan (2006) stated that if teachers intend to help students to develop the skills and competencies of knowledge-creation, professional knowledge should be developed among teachers by having the necessary experience. Figure 2 shows the components of flawed change theories and the topic discussion in Malaysian context.

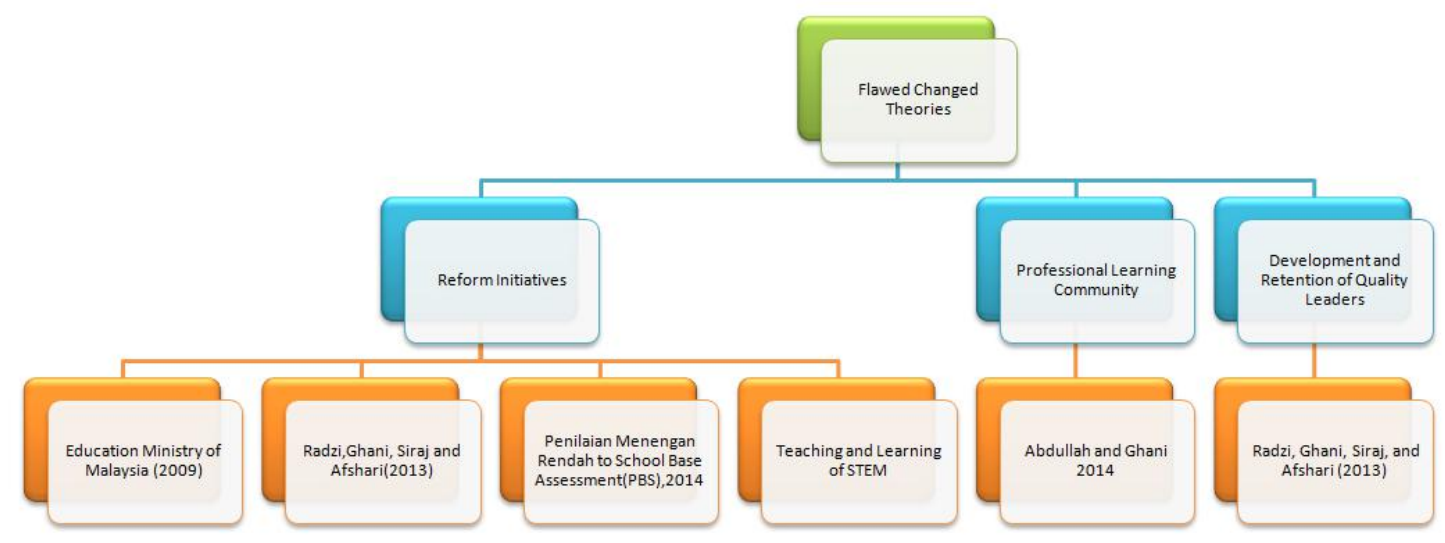

Figure 2. Flawed Change Theories

Fullan highlighted on initiatives taken where fund was provided for external improvement. However the final outcome was the districts were unable to change and improve practice on a large taken where fund was provided for external improvement scale (Allen, Osthoff, White,and Swanson, 2005) when it comes to district reform initiatives. In Malaysia, the operation expenditure allocated for the primary and secondary education accounted for nearly half the total education operating expenditure as a whole (Kementerian Pelajaran Malaysia, 2009). As the main provider of education funds for primary, secondary and higher level of schooling, the federal government of Malaysia through the Ministry of Education and Ministry of Higher Education contributed about 98\% of the total financing (Shahril@Charil Marzuki, 2008). The government formally recognized selected schools with guided financial autonomy known as Pusat Tanggungjawab (PTj) or Autonomy Center (Responsibility Center) was created to ensure allocation are provided. However, the failure of some principals to allocate resources based on the school objectives and priorities shows weaknesses on the division of fund. Similar to what Fullan had claimed, the fund provided fail to bring improvement as expected in certain schools. Radzi, Ghani, Siraj, and Afshari (2013) highlighted that the School Audit Division in its Annual Report has reported that some principals of PTj schools failed to list their objectives based on priorities and to provide a proper strategic plan for schools to reach their objectives (Kementerian Pelajaran Malaysia, 2007).

The Malaysian public examination taken by form 3 students is known as 'PenilaianMenengah Rendah' (PMR) national examination was replaced with 'Pentaksiran Berasaskan Sekolah'(PBS) or School Base Assessment in 2014. In 2016, a student's 'Ujian Pencapaian Sekolah Rendah' (UPSR) or Primary School Achievement Test, grade will no longer be derived from a national examination alone, but from a combination of School Base Assessment (PBS) and the national examination. The format of the Malaysian Certificate ofEducation or 'Sijil PelajaranMalaysia'(SPM) remains the same, with most subjects assessed through the nationalexamination, and some subjects through combination of examinations and centralised assessments. 
Initial feedback on the rollout of PBS suggests that teachers have yet to fully grasp the magnitude of the change. Some teachers and schools are also struggling to develop their own assessment tasks and instruments for the school assessment component (Malaysian Blueprint, 2013-2025). However, it is highlighted by Sudha and Hanipah (2016) that when shaping a curriculum it is important to have characteristics like interdisciplinary, research intensiveness, community engagement, academic literacy and global connectedness into it and the successfulness of the implementation is still doubtful(Nair and Hussin, 2016) in higher education in Malaysian context. Therefore school or higher learning institutions should take serious consideration on the characteristics for improvement. For instance, the Ministry of Education, Malaysia upholds ICT as an enabler to propel education to greater heights (Ministry of Education, Malaysia, 2006). However, the challenge lies in the principal's autonomy to implement change due to the hierarchical organizational structures and centralized school management.

In addition, the current heavy content of STEM (Science, Technology, English and Maths) curriculum places greater emphasis on content at the expense of practical aspects, and does not sufficiently emphasise its relevance to everyday life. This makes it more difficult for students to understand STEM's value or usefulness to them (Blueprint, 2016). Recent ranking of 'PISA 2015 Average Scores', Malaysian was ranked 446 for Maths, Reading 431 and Science 443, compared to Singapore which was first in all three (Business Insider, 2016). Currently, $20 \%$ of schools have Science labs that are damaged and no longer functional. Some schools also lack modern equipment and facilities (Blueprint, 2016). This makes the effective teaching and learning of STEM, especially through the use of practical lab work, more challenging to deliver and affects the interest of students. Another concern is that the number of students enrolled in Science, Technology, Engineering and Mathematics (STEM)-related programmes in higher secondary and tertiary levels is on a decline (The New Straits Times, 2016). The STEM curriculum serves to educate students in an interdisciplinary and applied approach. Last year, it was reported that the target for students enrolling in the stream is not being met annually at the school and tertiary levels. Those in the know have warned that not having a sufficient STEM-related workforce will lead to further technical dependency on foreign workers (The New Straits Times 2016). The main reason students shy away from STEM subjects were because many experienced difficulty and complexity in grasping the basic conceptual knowledge. Meanwhile, research has shown a direct correlation between the use of STEM curriculum with preschoolers and an increase in collaboration skills, vocabulary, and the ability to create and discuss scientific relationships (The New Straits Times, 2016).

The Malaysia Education Blueprint 2013-2025 has outlined strategies through various initiatives to enhance science teaching and learning, including pre-service training and ongoing professional development for teachers. Malaysia also has been liberal with funds used for educational purposes especially in higher learning institutions (Cheong, Hanipah, Sudha, Noorzareith, Noraiti and Zainuddin, 2016). The government's policy in education, particularly higher education is to bring it in line with the country's manpower planning and to provide the country with the right the right and adequate supply of trained manpower to keep pace with economic growth 2030 in future (EPU, 2016). Fullan admits, standards, assessment, curriculum and professional development are encouraged yet they are as quoted, "seriously incomplete theories action because they do not get close to what happens in classrooms and school cultures" (Fullan, 2006) and also difficulty in gaining results in the learning.

Fullan mentioned Professional Learning Communities (PLC) in his article which involves communities of learners where teachers and school leaders work together to improve learning conditions and results of students in given schools (Fullan, 2006). A study by Abdullah and Ghani (2014) in Professional Learning Community in Secondary Schools in Malaysia showed that the teachers can be active in their learning and improve their schools as to enhance the learning performance of the students in the first four characteristic dimensions referred to the practice of shared values, goals, mission and vision among teachers which play an important role in shaping the PLC in secondary school. Also, it reveals the importance of principals as key leaders play an important role in shaping the PLC in their respective schools, as to provide support and guidance to teachers. In addition, collective learning and application dimension also have four characteristics which showed teachers are more focused on their need to improve work performance and improve teaching methods. On the other hand, the secondary schools in Malaysia are very much focused on the revision of the 
student workbook and hold a formal observation whereas, peer observations is poorly implemented. However, the schools that have adopted the PLC shows all the teachers work harder to ensure they continue to be implemented properly and constantly improving for a better future (Abdullah and Ghani, 2014). As highlighted by Fullan, he focuses on learning, a collaborative culture with best practices, action orientation and commitments will bring results. This can be identified in Ghani's sample of 676 teachers, whom exhibits shared and supportive leadership, shared value, objectives, mission and vision, collective learning and application, personal learning practices and supportive conditions.

\section{Theories of Action with Merit}

Fullan (2006) has identified motivation, capacity building with a focus on results, learning and changing context, bias for reflective action and tri-level engagement as the seven core premises that underpin change knowledge (Refer Figure 3). Figure 3 shows each case study base on Fullan's theories of action with merit in Malaysian context. Motivation is a strong desire or passion in a person that encourages the person to try and do something in order to succeed. It is a construct that is built out of individual learning activities and experiences, and it varies from one situation or context to another (Bandura, 1997) and Fullan has stated it being one of the core premise for change knowledge. The International Islamic University Malaysia's Alumni organized an educational trip in a rural school in Sabah (The Borneo Post, 2017). According to the article, the key themes which became the emphasis of the motivation program are to increase awareness among students on the importance of having ambition in life, time management, and strategy for the UPSR examination. Some of the activities are motivational talks and group discussion with facilitator. The university is concerned about the education performance of students in Sabah and is committed in organizing more motivational programs in rural areas this year voluntarily(The Post Borneo,2017.

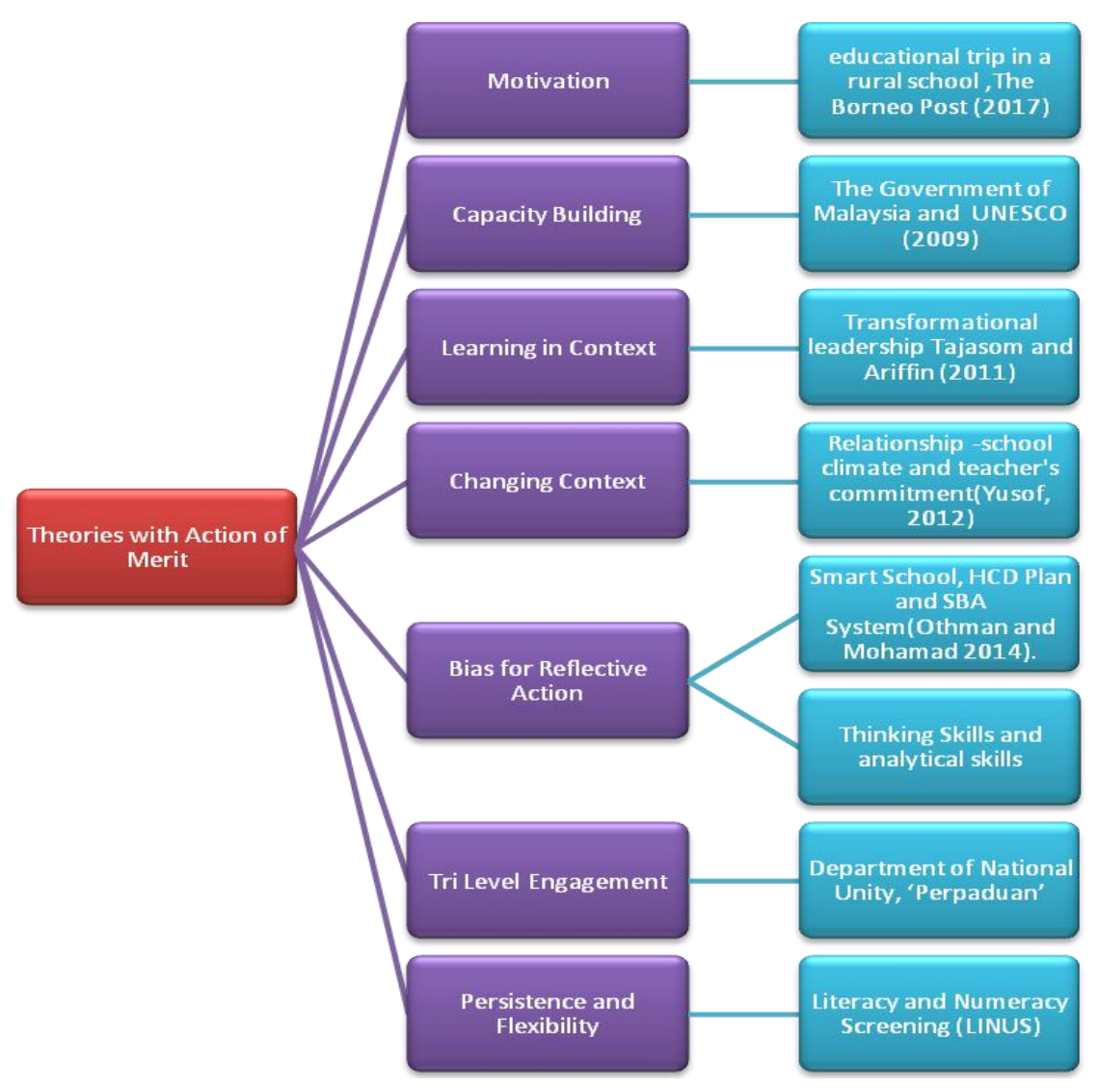


Figure 3. Theories of Action with Merit

Capacity building, with a focus on results, is crucial (Fullan, 2007). Fullan had defined it as any strategy that increases the collective effectiveness of a group to raise the bar and close the gap of student learning. The author believes that in change theory, capacity building comes first followed by judgement, as it is most motivational as the theory specifies that nothing will count unless people develop new capacities. Too often the evaluation and monitoring component of a reform is not given the time and resources it really requires; new programmes are planned before the evaluation is complete, or an evaluation is cut altogether due to budget shortfalls (OECD, 2009). The Government of Malaysia and the United Nations for Education, Sciences, Culture and Communications Organization (UNESCO) signed a Memorandum of Understanding (MOU) on 15th November 2011 under the Malaysia UNESCO Cooperation. The establishment of Malaysian Cooperative Trust Fund which will contribute to enhance South-South cooperation for capacity building in education and science for the benefit of the Least Developed Countries, Small Island States in Asia and the Pacific and in support of the Priority Africa agenda of UNESCO (OECD, 2009). This will involve the participation of national experts, practitioners, international experts, senior advisors and climate change negotiators. As Fullan (2007) states, the more one invests in capacity building, the more one has the right to expect greater performance.

The third and fourth premises that Fullan touched on are learning and change in context. In Fullan's article, he pointed out that Elmore (2000) pinpointed issue that there is almost no opportunity for teachers to engage in continuous and sustained learning as they are less observing and less being observed! Fullan further stresses the need to have "capacity to change the larger context" where schools and districts learn from each other. A larger context can produce positive or negative impact and he highlights the importance of principals. Knowledge and motivation would be the plus points however conflicts, bureaucracy and managerial issues would be challenges that one meets along it. Recruiting top-performing principals and rewarding good principal performance are both important. Providing strong principal training is useful, too. Learning at work-learning in context-occurs, for example, when principals are members of a district's inter-visitation study team for which they examine real problems - and the solutions they have devised — in their own systems. Learning out of context takes place when principals go to a workshop or conference. Such learning can be valuable for further development, but it is not the kind of applied learning that really makes a difference. A research by Tajasom and Ariffin (2011) in urban secondary schools in northern Malaysia found that transformational leadership has an effect on four aspects of school climate (affiliation, innovation, professional interest, and resource adequacy) whereas transactional leadership only effect participatory decision making. Yusof (2012) had conducteda study to analyze the relationship between school climate and teachers" commitment. The population involved five primary schools in Penang, Malaysia. The finding showed that transparency of the institution level and teachers' commitments in the five schools were high. Teachers' professional behavior also contributes towards teachers' commitment. In a study by Raman, Ling and Khalid (2015), which focused on five excellent schools in the district of Kubang Pasu, Kedah, showed that dimensions such as collaborative leadership, teachers' professional behavior; and working pressure have positive significant relationship with teachers' commitment. Teachers' professional behavior was deemed as the determinant for teachers' commitment. In conclusion, the result findings of the study can contribute to all types of schools and school administrators. Malaysia realizes the need for constant renewal in its teaching profession especially when rapid changes are made in Malaysia's education system (PIER, 1996). In action-research, 'theories' are not validated independently and then applied to practice. They are validated through practice Elliot, 1991 as cited in PIER, 1996. Despite the advancement of new instructional technologies, the teachers' role in the classroom cannot be by-passed, rather it should be strengthened with the teacher now playing the role of facilitating the acquisition of knowledge - the constructivist (PIER 1996).

Fullan (2006) stated that one needs to dig a bit deeper to understand the theory of action underpinning the bias for reflective action. He recalls back of Dewey's words, that " it is not that we learn by doing but that we learn by thinking about what we are doing". One has to agree with Fullan who concluded that people learn through 
doing, reflection, inquiry, evidence, more doing and so on. When talking about thinking skills, a great deal has been done to promote the teaching of higher order thinking skills in Malaysian classroom (Rajendran, 2001). It was also suggested that modern skills like for instance precise and rational thought, training in basic logic, reasoning and critical thinking are essential for all students. This clearly notes of the intention of promoting thinking skills in Malaysian schools such as Smart School, Human Capital Development Plan and School Base Assessment System (Othman and Mohamad, 2014).

Previously, a study conducted by Rajendran (2001) among Malay and English Language teachers perceived that they were better prepared in term of their knowledge and pedagogical skills rather than teaching higher order thinking skills. And yet, they are expected to teach the content as well as higher order thinking skills. This is aligned with what Hashim (2002) who stated that "the biggest problem with the teaching of critical and creative thinking is teachers' lack of understanding and knowledge and the accompanying skills on thinking. No proper education and training on thinking have been offered to all teachers, especially in-service teachers whereas the Ministry and subject teachers prefer to adopt the infusion approach in teaching thinking". Choy and Cheah (2009) noted that teachers did not seem to understand the requirement needed to cultivate critical thinking among students. Overall, the transformation of the Malaysian education system particularly in the area of thinking skill development is an ongoing process. It is yet to achieve its mature level (Othman and Mohamad 2014). There are many initiatives taken by government and private sectors to overcome these problems. Recently, there was a workshop conducted with 48 secondary school English teachers. Sponsored by StarNie (Star Newspaper in Education), it was aimed to convey creative methods of using newspaper as a resource in language classes. StarNie noted that HOTS (Higher Order Thinking Skills) and ' $21^{\text {st }}$ Century Learning Skills' are terms that are heavily used of late (The Star Malaysia, 2017). It is hoped for teachers to become better, to come out and listen to people who inspire. It is expected that this workshop will be held up to September, 2017, and primary and secondary teachers are encouraged to participate. There are many initiatives taken in all quarters in encouraging critical thinking. For instance, the KDU's College Damansara Jaya campus, held a two hour competition aimed to expose pupils to HOTs in Mathematics as well as the Sakamoto Math method - a method originated from Japan that provides a simple yet systematic and structured technique to analyse questions in a logical way (The Star Malaysia, 2017). The idea is that they need to be able to think and answer without relying heavily on text-books. There were about 300 participants from 14 schools in Petaling Utama, Selangor that took part. A research by Ganapathy, Singh,Kaur and Kit (2017) identified that there are several important insights on the potential opportunities of technologies in facilitating higher order thinking but success lies on the tasks that are appropriately designed for promoting the content. This goes at par with the announcement of the Prime Minister Najib Razak on introducing computational thinking and computer science in the curricula for both Malaysian primary and secondary schools starting from 2017 under a \#mydigitalmaker movement and 9200 teachers will be trained for this purpose (TodayOnLine, August 11, 2016).

Tri-level engagement is essential for systemic educational reform efforts. This engagement includes the school/community, district, and state. Fullan (2006) explained that complete alignment of levels is often unachievable, but a "permeable connectivity" is ideal, where "mutual interaction and influence within and across the three levels" takes place and results in change in the system concurrently. However, the missing thing would be the strategy about school or its district culture. A good example of tri-level engagement in Malaysian context can be seen through the initiative under the Department of National Unity, 'Perpaduan' pre-school were established in urban areas where a 'friendly neighbor-hood scheme' existed. Each preschool class has a Preschool Coordinating Committee made up of members of the local community who provide advice on the operation of the preschool and organize various activities for parents. Classes are conducted at community halls (rented or free of charge), housing estates, private property, shop-houses (rented) or built by the Ministry. In 2007, there were 1496 'Perpaduan' preschools with a total enrolment of 38,952 children (Ball 2007). The concern now is to make sure that all these core premises are cultivated and to achieve this there should be persistence and flexibility. 
Fullan, 2007 claims that using change knowledge for school and system improvement yields result and it matters. In Malaysia, The Literacy and Numeracy Screening (LINUS) programme was introduced aiming at ensuring that all Malaysian children acquire basic literacy and numeracy skills after three years of mainstream primary education. The main aim of the training programme is to introduce the teachers to the differentiated pedagogical skills for pupils with learning disabilities and techniques to identify pupils with special needs and learning difficulties (Kang Soon Chen 2012). A research was conducted by Wei and Hutagalung (2014) to determine the effectiveness of LINUS screening test. The study identified that the programme does benefit students who fall behind in education system and remedial coaching can be given for students to catch up. Here as stated by Fullan (2007) being persistence and flexible is built in the action theory.

\section{Prospects for future use of change knowledge}

Surveying Fullan's writings and line of products, it is next to impossible to identify where he actually stands on the goals and purpose of school reform. Ten years ago, he lauded George W. Bush's No Child Left Behind agenda, while expressing reservations about the "too narrow tests, short time lines, little capacity building, and punitive strategy." Since then, he has beenserving on the Advisory Board of Microsoft's Partners in Learning and advocating large-scale system change that produces "real results." Conservative school reformers remain as sceptical as teacher unionists about Fullan's real motives, strategies, and objectives. Michael Fullan Enterprises Inc. rides the sharp edge of the North American school reform divide. "A big feature of our work," he now says, "is to play down accountability in favour of capacity building, and then re-enter accountability later." All of the new private sector services are tailored to provide "solutions" to the problems posed by reform. Fullan (2006) seem to have so many ideas of reformation. However most that has been undertaken have proven successful in Malaysia. Consider how governmental policy and accountability are re-framed as a problem which the private solution provider can help to solve. As a result, parents are driven to seek out solutions outside the system for their children, or leave the public school system altogether.Some of the challenges highlighted in Malaysian STEM implementation were the necessity of adopting and implementing a holistic approach to learning, the need to consider the applied dimension of knowledge (what we know is as important as what we can do with that knowledge), necessity of revising the traditional structure of the curriculum, the organization of learning experiences, the teaching approaches, and the assessment systems (Amadio 2015). The future of educational change is very much a matter of if accountability and professional learning community will be developed and draw on each others' essential resources. Fullan ,2006 summarized that the ultimate goal of change was when people visualize themselves as shareholders with a stake in the success of the system as a whole, with the pursuit of meaning as the intangible key. Of course one need to agree as quoted by Fullan (2006) large scale successful reform occurs in a thousand small ways during the journey. Fullan warned not to go on a journey without equipped with an active and open-ended grasp of change knowledge. In other words be more receptive to alternative strategies, don't wait before it happens, and be among the promoter!

\section{Limitation to Fullan's Theory}

More than ten years have passed since the publication of the New Meaning of Educational Change (Fullan 2007) and great educational changes have already taken place in schools all over the world. It is for sure that education stakeholders could gain abundantly by reading this book. However, could the unsatisfied working conditions of educational stakeholders greatly be improved even if all the educational changes mentioned by Fullan have already occurred? The answer may not be that positive. In fact, many teachers and principals all over the world today still overwork because they are occupied by the same duties as those ten years ago, though the former are more certain and collaborative. For example, instead of handing out papers, giving remarks, inputting grades into computers and finally analyzing and evaluating the grade, teachers could input questions on computers and then release to students by using a virtual learning platform. With the help of educational technology, they could have courses online at their own paces, and thus student-directed change can be 
achieved. As a matter of fact, educational revolution has already taken place in some schools where all courses are taught online and where teachers mainly focus on teaching instead of "controlling students and organizing classes". Florida Virtual School (FLVS) is a public school, where all courses are taught online. And the online courses are just as real as the dedicated, certified teachers who teach them. As far as Malaysia is concerned, the announcement of the Prime Minister of integrating computational thinking and computer science in the curricula is plausible with the $21^{\text {st }}$ century need is a positive move towards changes. Changes should always be there if a country wants to compete globally. It is without doubt that for every decision will have drawback, however this should not stop a country from producing intellectual community with high income as per the country's vision. Of course, the vision and objectives are not something that can be achieved overnight, it takes time and careful planning.

\section{Conclusion}

The review above can be summarized with a few findings. First, theory of change is both a process and a product, second the quality of a theory of change process rests on 'making assumptions explicit' and making strategic thinking realistic and transparent. Next, the time and resource needed to work effectively with theory of change needs to be taken seriously. Finally, working with theory of change thinking can be challenging but it can create a strong organising framework to improve programme design, implementation, evaluation and learning (Vogel, 2012). The issues raised by Fullan need much investigation. Not all outcomes are negative as far as changing theory is concerned. School structure will continue to evolve, and the reform theories proven effective by research will continue to be refined in this $21^{\text {st }}$ century.

\section{Reference List}

Allen, L.E., Osthoff, E., White, P. and Swanson, J., 2005. A Delicate Balance: District Policies and Classroom Practice. Cross City Campaign for Urban School Reform.

Abdullah, Zuraidah, and Muhammad Faizal A. Ghani. 2014."Professional Learning Community in Secondary Schools Community in Malaysia." Journal of Education and Learning (EduLearn) 8.3 : 227-248.

Amadio.M., 2015. International Stem High-Level Policy Forum“Evidence-Based Science Education In Developing Countries”, 26-27 May 2015, Kuala Lumpur, Malaysia.

Ball, Jessica, 2011. "UNESCO, 2010."

Bandura, A., 1997. Self-efficacy: The exercise of self-control.

Blueprint, M.E., 2016. Blueprint 2013-2025.(2013). Ministry of Education, Malaysia.

Barth, R.S., 1990. Improving schools from within: Teachers, parents, and principals can make the difference. Jossey-Bass Inc., Publishers, 350 Sansome Street, San Francisco, CA 94104-1310.

Business Insider, Malaysia. 2016, Dec 7. Retrieved from http://www.businessinsider.my/pisa- worldwide-ranking-of-mathscience-reading-skills-2016-12/?r=US\&IR=T\#5VlcY1PbFfxT56vS.97on 17/4/2017).

Brest, P., 2010. The power of theories of change. Stanford Social Innovation Review, 8(2), pp.47-51.

Hopkins, D., 2003. School improvement for real. Routledge.

Cheong, K. M., Hanipah, H., R Sudha, N., Noorzareith, S., Noriati, A. K., and Zainuddin, J. (2016). 
The Relevance Of The Seven Premises Discussed By Fullan's Change Theory In Higher Education In Malaysia. The Social Sciences, 11(9), 2206-2209.

Choy, S.C. and Cheah, P.K., 2009. Teacher perceptions of critical thinking among students and its influence on higher education. International Journal of teaching and learning in Higher Education, 20(2), pp.198-206.

Elmore, R.F., 2000. Building a new structure for school leadership. Albert Shanker Institute.

Elmore, R.F., Fiarman, S.E. and Teitel, L., 2009. Instructional rounds in education: A network approach to improving teaching and learning. Harvard Education Press. 8 Story Street First Floor, Cambridge, MA 02138.

Eseryel, D., 2002. Approaches to evaluation of training: Theory \& practice. Educational Technology \& Society, 5(2), pp.93-98.

Eyal, O., 2009. Degeneracy, resilience and free markets in educational innovation. Systems Research and Behavioral Science, 26(4), pp.487-491.

Farr Gabriele, S., 2002. The "Roundtable" for school learning and planning groups: planting a seed for systemic renewal. Kybernetes, 31(9/10), pp.1361-1368.

Fullan, M., 2006. Change theory: A force for school improvement (Centre for Strategic Education Seminar Series Paper No. 157). Victoria: SCE.

Fullan, M., 2007. The new meaning of educational change. Routledge.

Fullan, M., 2007. Change theory as a force for school improvement. In Intelligent leadership (pp. 27-39). Springer Netherlands.

Ganapathy, M., Singh, M.K.M., Kaur, S. and Kit, L.W., 2017. Promoting Higher Order Thinking Skills via Teaching Practices. 3L: Language, Linguistics, Literature $囚, 23(1)$.

Hargreaves, A., 1994. Changing teachers, changing times: Teachers' work and culture in the postmodern age. Teachers College Press.

Hashim, R., 2002. Investigation on the teaching of critical and creative thinking in Malaysia. Jurnal Pendidikan Islam, 10(1), pp.39-56.

Henk, M., 2010. Change theories in education. We Teach We Learn.

Kang Soon Chen. Linus programme for Early Child, 2012, Sept 5.http://www.thestar.com.my/news/nation/2012/09/05/linus-programme-for-early-learning/.

OECD. Centre for Educational Research and Innovation (CERI), 2009. Working out change: systemic innovation in vocational education and training. OECD, Paris, France.

Othman, N. and Mohamad, K.A., 2014. Thinking Skill Education and Transformational Progress in Malaysia. International Education Studies, 7(4), pp.27-32.

Programme for Innovation, Excellence \& Research (PIER). 1996. Report by Educational Planning Research Division: Ministry Of Education Malaysia.

Rajendran, N., 2001. The Teaching of Higher-Order Thinking Skills in Malaysia. Journal of Southeast Asian Education, 2(1), pp.42-65. 
Raman, A., Ling, C.C. and Khalid, R., 2015. Relationship between school climate and teachers' commitment in an excellent school of Kubang Pasu District, Kedah, Malaysia. Mediterranean Journal of Social Sciences, 6(3 S1), p. 163.

Sudha, N.R., and Hanipah, H. (2016). Shaping The Curriculum: A Characteristics Approach And Its Impact On Teaching And Learning. Social Sciences, 11(9), 2054-2057.

Tajasom, A. and Ariffin Ahmad, Z., 2011. Principals' leadership style and school climate: teachers' perspectives from Malaysia. International Journal of Leadership in Public Services, 7(4), pp.314-333.

The Borneo Post (Sabah): 2017-02-09 - Motivation programs for rural students. Retrieved fromhttps://www.pressreader.com/malaysia/the-borneo-post sabah/20170209/281547995634176.

The New Straits Time. 2016-3-15. Science too daunting too many students. 15-3-2016. http://www.nst.com.my/news/2017/03/151648/science-too-daunting-too-many-students.

The Star NIE, PressReader, 2017-3-5. Putting the Fun Back in Reading. Retrieved from https://www.pressreader.com/malaysia/the-star-malaysia/20170305/283029759397893.

Vogel, I., 2012. Review of the use of 'Theory of Change'in international development. UK: Department for International Development (DFID).

Wei, Y.S. and Hutagalung, F., 2014. LINUS assessment accordance with the cognitive level among year 1 students in a School Klang District. Manag. Technol. Knowl. Serv. Tourism Hosp, 1, pp.123-126.

Yusof, N.M., 2012. School Climate and Teachers' Commitment: A Case Study of Malaysia. 